\title{
Seasonal variation in coronary heart disease in Scotland
}

\author{
A S Douglas, M G Dunnigan, T M Allan, J M Rawles
}

\begin{abstract}
Study objective - Seasonality of coronary heart disease (CHD) was examined to determine whether fatal and non-fatal disease have the same annual rhythm.

Design - Time series analysis was carried out on retrospective data over a 10 year period and analysed by age groups $(<45$ to $>75$ years) and gender.
\end{abstract}

Setting - Data by month were obtained for the years 1962-71. The Registrar General provided information on deaths and the Research and Intelligence Unit of the Scottish Home and Health Department on hospital admissions.

Subjects - In Scotland, between 1962 and 1971, 123000 patients were admitted to hospital for CHD, of whom 29000 died. There were a further 97000 CHD deaths outside hospital. These two groups were also examined as one (coronary incidence) - that is, all coronary deaths and coronary admissions discharged alive. Statistical analysis and main results Where there was a single annual peak, the sine curve was analysed by cosinor analysis. When there were two peaks the analysis was by normal approximation to Poisson distribution. In younger men (under 45 years) admitted to hospital there was a dominant spring peak and an autumn trough. A bimodal pattern of spring and winter peaks was evident for hospital admissions in older male age groups: with increasing age the spring peak diminished and the winter peak increased. In contrast, female hospital admissions showed a dominant winter/summer pattern of seasonal variation. In male and female CHD deaths seasonal variation showed a dominant pattern of winter peaks and summer troughs, with the winter peak spreading into spring in the two youngest male age groups. CHD incidence in women showed a winter/summer rhythm, but in men the spring peak was dominant up to the age of 55 .

Conclusions - The male, age related spring peak in CHD hospital admissions suggests there is an androgenic risk factor for myocardial infarction operating through an unknown effector mechanism. As age advances and reproduction becomes less important, the well defined winter/summer pattern of seasonal variation in CHD is superimposed, and shows a close relationship with the environment, especially temperature, or the autumn and early winter fall in temperature.

( $(\mathcal{F}$ Epidemiol Community Health 1995;49:575-582)

Studies of seasonal variation in coronary heart disease (CHD) are almost entirely based on data derived from national registers of deaths. Studies based on seasonal variation of $\mathrm{CHD}$ hospital admissions are few. Dunnigan et $a l^{1}$ found a bimodal pattern of seasonal variation with spring and winter peaks in a study of 47281 admissions to all Scottish hospitals in 1962-66 in the diagnostic category ICD 420.1. The spring peak declined with age, while the winter peak became more prominent. Surprisingly, no further large studies of seasonal variation in CHD incidence have been published, but two small studies ${ }^{23}$ have similarly challenged the conventional belief that all seasonality of $\mathrm{CHD}$ follows a winter/summer rhythm. The present investigation extends the sample size of the original Scottish study to 10 years (1962-71), and examines the effects of age and sex in more detail.

\section{Methods}

Between 1962 and 1971 inclusive, the Scottish Home and Health Department recorded $123000 \mathrm{CHD}$ discharges/admissions to all Scottish hospitals, of whom 29000 died. The General Register Office for Scotland recorded a further 97000 deaths from CHD outside hospital over this period. Between 1962 and 1967, the ICD 7th Revision (420.1) was used, and thereafter the 8th Revision (410). Deaths and admissions were analysed by gender, age, and month of occurrence (corrected to 31 day months). Month correction causes an annual total greater than the true total (see tables).

The General Register Office for Scotland also provided data on births between 1962 and 1971.

\section{STATISTICAL ANALYSIS}

Cosinor analysis ${ }^{456}$

This was used to determine the significance of seasonal variation in CHD events. This technique forces a sine curve on the data, the peak being six months ahead of the trough. The amplitude of seasonal fluctuation is expressed as a percentage above the mean for the month of highest value (acrophase, zenith, or peak). Cosinor analysis is reliable only if the data fit a single sine curve and may be invalidated by two peaks, as in part of our data. Significance 

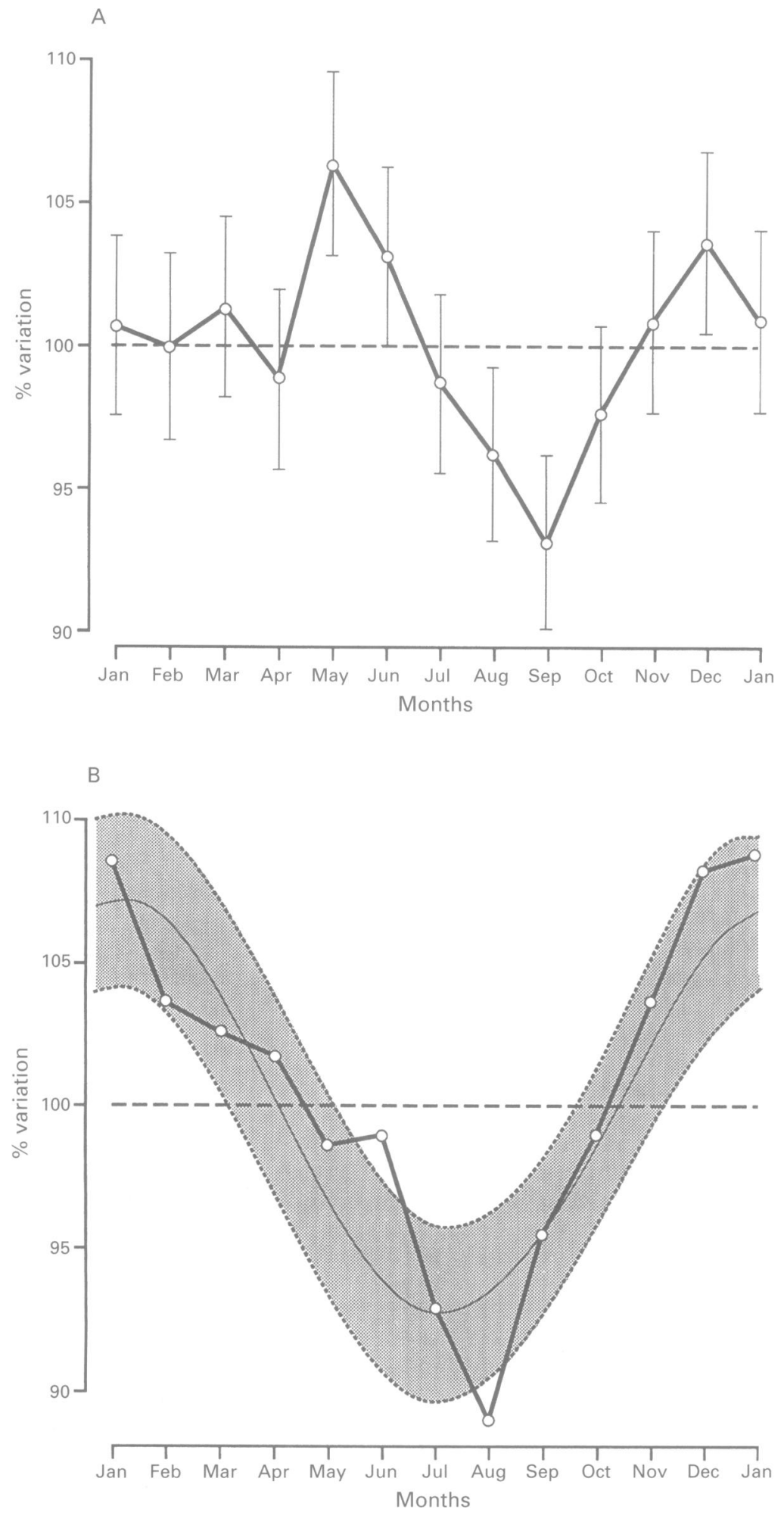

Figure 1 (A) All male admissions with coronary heart disease (CHD). All ages examined by normal approximation to Poisson distribution and $99 \%$ confidence intervals are shown. May and December are significantly raised and August and September are significantly lowered. (B) All female admissions with CHD. All ages examined by Cosinor analysis. The sine wave and $95 \%$ confidence intervals are shown. $R$ values and the amplitude and level of significance are given in table 2.

refers to the presence or absence of seasonality. Ninety five per cent confidence limits are established.

In cosinor analysis, the year is taken as $360^{\circ}$ and the midpoint of each month of the year is assigned an angular value $t$, for January $\left(15^{\circ}\right)$ through to December $\left(345^{\circ}\right)$. Multiple regression analysis is completed between monthly data and $\sin (t)$ and $\cos (t)$. This analysis gives the multiple correlation coefficient (r), its statistical significance (p), and the angular position in the year (converted to the nearest month) where the fitted sinusoidal regression line has its highest value. The technique is exemplified in figure $1(\mathrm{~B})$.

\section{Normal approximation to Poisson distribution (NAPD)}

This statistical method was applied to the whole data set but was of particular value in the examination of the two peaks in the annual rhythm of non-fatal coronary onsets in patients arriving alive at hospital. In using this, two assumptions are made, firstly, that the population at risk is large compared with the number of hospital coronary admissions and, secondly, that these appear "independently" in time.

The technique is exemplified (fig 1(A)) for 79746 male hospital admissions. The expected monthly value was calculated allowing for different month-length.

The estimated standard error of a Poisson distribution is the square root of the actual value. Ninety nine per cent confidence intervals are used (see fig 1(A)). Significance refers to the $1 \%$ level.

\section{Results}

"Hospital admissions" refer to patients who arrived alive at the hospital, whether they subsequently died or survived. "Deaths" refers to total deaths, including those at home plus those in hospital. "Coronary incidence" refers to all coronary deaths plus all coronary admissions discharged alive examined as one group.

MALE HOSPITAL ADMISSIONS (FIGS 1(A), 2, AND 4, TABLES 1 AND 2)

Total male CHD hospital admissions show a spring peak with a late summer/early autumn trough and an early winter peak. Using NAPD, the numbers for May and December are significantly higher, and those for August and September significantly lower, than the annual average (see figs 1 (A) and 4). The spring peak is dominant in males under 45 years; this is significant on cosinor analysis. The bimodal pattern of spring and winter peaks is evident in older decades, with the spring peak waning and the winter peak waxing with age. This bimodal pattern of seasonal variation invalidates cosinor analysis except for the youngest age group $<45$ years. The amplitude of the spring peak exceeds that of the winter peak in all but the oldest age group ( $>75$ years). In patients aged between $55-74$ (60\% of the total series) May, but not December, is significantly higher on NAPD (see fig 4).

FEMALE HOSPITAL ADMISSIONS (FIGS 1(B), 2, 3, AND 4, TABLES 1 AND 2)

Total female CHD hospital admissions show a winter peak and a summer trough, demonstrated by cosinor analysis (fig $1(B)$ ) and 

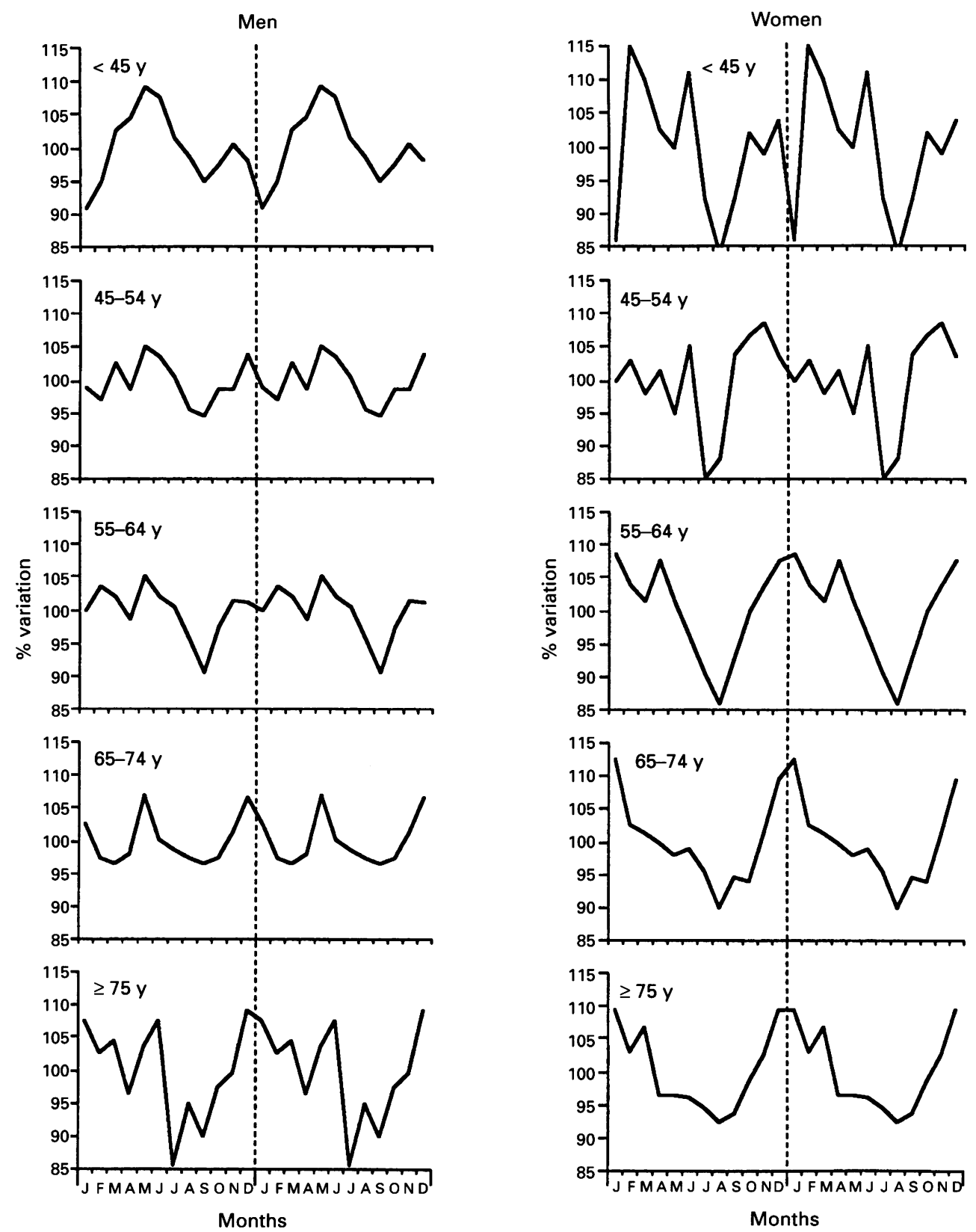

Figure 2 Patients admitted to hospital with coronary heart disease and who were discharged (alive or dead) from hospital (1962-71) in relation to sex, and age group. The vertical axis is scaled to percentages above and below the mean monthly value (100\%). The horizontal axis gives the time by month. The second half of each diagram repeats the first half to illustrate the pattern of seasonal variation more clearly.

confirmed by NAPD (fig 4). Using the latter, December and January are significantly higher than the annual average at the $99 \%$ confidence interval and July, August, and September are significantly lower. The numbers in the two youngest age groups do not allow the expression of a clear pattern of seasonal variation. The three oldest age groups showed a dominant and significant pattern of winter peaks in admissions (NAPD fig 4).

MALE DEATHS (FIGS 3 AND 4, TABLES 1 AND 2) Overall, the rhythm is winter/summer, with the three older age groups having a peak in January. The peak is in February for the $45-54$ years age group, and in March for the under 45 group. In all age groups the rise in deaths in the autumn is precipitous. In the oldest age group the rises and falls to and from the winter peak are almost symmetrical. The younger the age group the slower the fall from the peak, because of a spring "shoulder". The older the age group, the greater the winter excess.

Of the 79000 male admissions, 17000 died in hospital. The latter deaths had a single, February peak, with an otherwise similar pattern of seasonal variation to that of male deaths as a whole. The amplitude of the seasonal variation, however, was smaller $(8 \cdot 7 \%)$ inside hospital than outside $(12 \%)$. The proportions in each age group that died inside and outside hospital were almost identical. The amplitude difference is not related to any age difference.

FEMALE DEATHS (FIGS 3 AND 4, TABLES 1 AND 2)

A significant pattern of winter/summer variation in deaths is evident in the four oldest age 

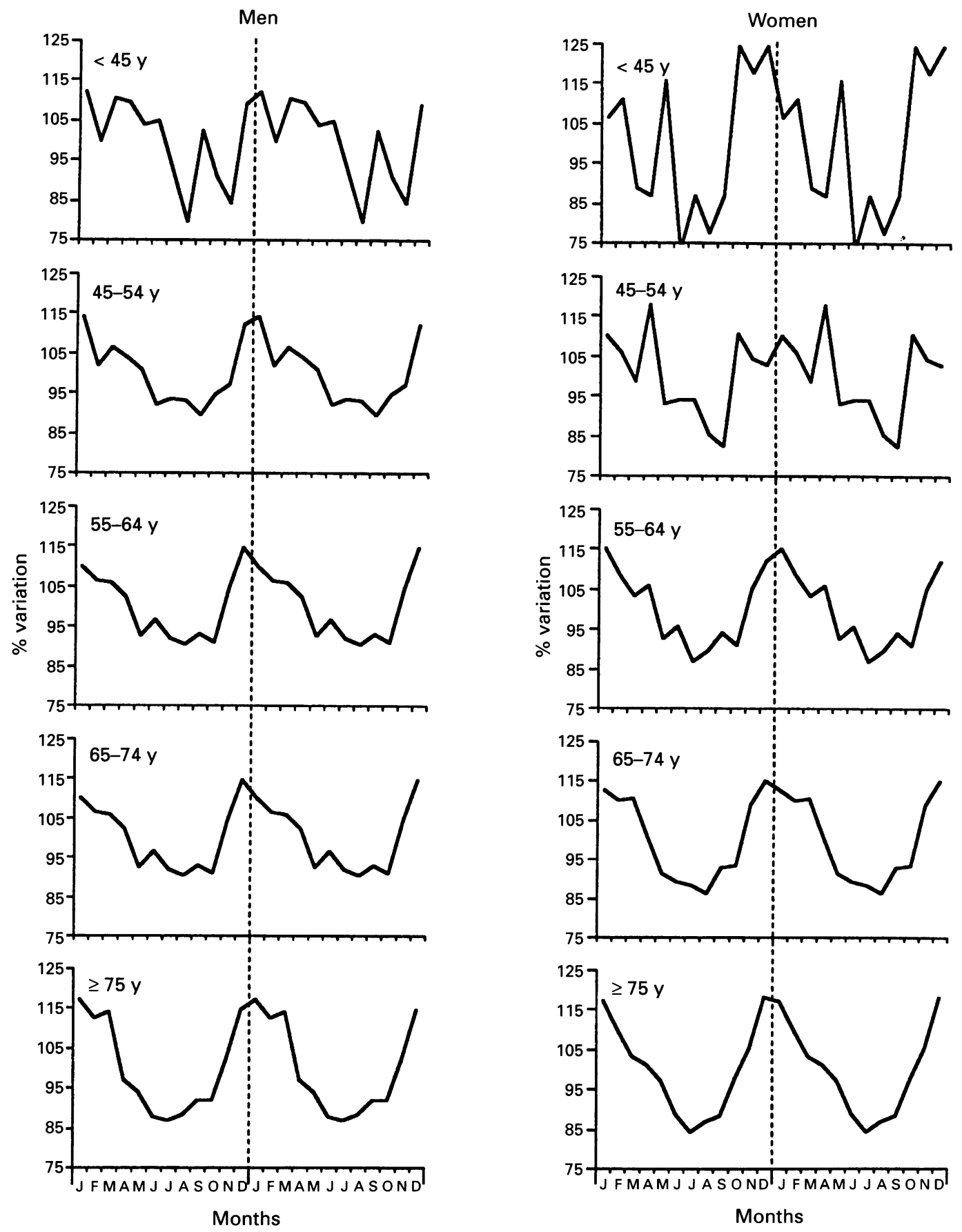

Figure 3 Deaths (1962-71) from coronary heart disease (in hospital or outwith) in relation to sex and age group. The vertical axis is scaled to percentages above and below the mean monthly value (100\%). The horizontal axis gives the value by month. The second half of each diagram repeats the first half to illustrate the pattern of seasonal variation more clearly.

groups. No clear pattern of seasonal variation is evident in the youngest age group, because of the small sample size. As with males, the seasonal excess increases with age.

The amplitude of the winter/summer seasonal variation in female deaths is substantially greater than that for female hospital admissions, as is that for male deaths.

CORONARY INCIDENCE: MEN AND WOMEN (TABLE 3, FIGS 4 AND 5)

Total coronary incidence shows on cosinor analysis in men that the spring peak is present in the $<45$ years age group and in the group age
$<55$ years (table 3 ). The addition of the deaths to admissions has given statistical significance on cosinor analysis in men under 55 years. Also, in males under 55 years on the NAPD ( $1 \%$ level) both May and December peaks are significant (table 3, figs 4 and 5). The May peak seen in hospital admissions of men 55-75 + was "drowned out" by the increasing deaths in these age groups when examined as coronary incidence, leaving only the winter peak (fig 5).

The number of women under the age of 55 years is relatively small and no significant peaks are found. A non-significant trend is to a winter peak style. Other female groupings show a winter peak (fig 4). 
Table 1 Deaths (outside and inside hospital) and hospital admissions (survived or died) due to myocardial infarction in Scotland 1962-71 in relation to gender, age group, and month of occurrence

\begin{tabular}{|c|c|c|c|c|c|c|c|c|c|c|c|c|}
\hline \multirow[t]{2}{*}{ Month } & \multicolumn{5}{|c|}{ Deaths in age groups } & \multicolumn{5}{|c|}{ Admissions in age groups } & \multicolumn{2}{|l|}{ Total } \\
\hline & $<45$ & $45-54$ & $55-64$ & $65-74$ & $75+$ & $<45$ & $45-54$ & $55-64$ & $65-74$ & $75+$ & Deaths & Admissions \\
\hline Men (\%) & (9) & $(22)$ & (37) & (23) & $(10)$ & (3) & (12) & (29) & (33) & $(22)$ & & \\
\hline Aug & 188 & 746 & 1714 & 1985 & 1345 & 586 & 1418 & 2367 & 1525 & 608 & 5978 & 6504 \\
\hline Sep & 242 & 718 & 1765 & 2016 & 1399 & 566 & 1403 & 2242 & 1506 & 577 & 6140 & 6294 \\
\hline Oct & 215 & 758 & 1723 & 1977 & 1400 & 580 & 1461 & 2415 & 1519 & 627 & 6073 & 6602 \\
\hline Nov & 199 & 781 & 1981 & 2242 & 1554 & 600 & 1466 & 2531 & 1589 & 640 & 6757 & 6826 \\
\hline Dec & 257 & $\underline{900}$ & $\underline{2173}$ & $\underline{2404}$ & 1740 & 584 & 1540 & 2519 & 1668 & 699 & 7474 & 7010 \\
\hline Jan & $\underline{265}$ & 9 & 2085 & 2470 & 1786 & 544 & 1467 & 2496 & 1610 & 697 & 7522 & 6814 \\
\hline Feb & $\overline{235}$ & $\overline{816}$ & $\underline{2015}$ & 2314 & 1712 & 566 & 1439 & 2570 & 1524 & 660 & 7092 & 6759 \\
\hline Mar & $\underline{261}$ & $\underline{855}$ & 2013 & 2217 & 1738 & 613 & 1520 & 2538 & 1514 & 671 & 7084 & 6856 \\
\hline Apr & $\underline{258}$ & 833 & 1944 & 2162 & 1477 & 624 & 1460 & 2455 & 1531 & 616 & 6674 & 6685 \\
\hline May & $\frac{200}{245}$ & 810 & 1754 & 1973 & 1434 & $\underline{651}$ & 1560 & 2643 & 1679 & 665 & 6216 & 7198 \\
\hline Jun & 247 & 738 & 1838 & 2024 & 1338 & 641 & 1535 & 2539 & 1571 & 690 & 6185 & 6976 \\
\hline Jul & 218 & 749 & 1749 & 1836 & 1321 & $\frac{71}{606}$ & 1497 & 2492 & 1535 & 546 & 5873 & 6676 \\
\hline Significance & $*$ & $* *$ & $* *$ & $* * *$ & $* * *$ & $*$ & NS & NS & NS & NS & $* * *$ & NS \\
\hline Women (\%) & (1) & (5) & $(17)$ & (35) & $(42)$ & (3) & (11) & $(29)$ & (35) & (22) & Total & \\
\hline Aug & 35 & 165 & 634 & 1236 & 1514 & 97 & 365 & 927 & 1144 & 761 & 3584 & 3294 \\
\hline Sep & 39 & 159 & 668 & 1336 & 1546 & 107 & 434 & 1004 & 1218 & 770 & 3748 & 3533 \\
\hline Oct & $\underline{56}$ & $\underline{214}$ & 646 & 1338 & 1713 & 118 & $\underline{442}$ & 1081 & 1216 & 810 & 3967 & 3667 \\
\hline Nov & $\underline{53}$ & $\overline{202}$ & 745 & 1563 & 1840 & 115 & 451 & 1121 & 1310 & 844 & 4403 & 3841 \\
\hline Dec & $\underline{56}$ & 199 & $\underline{797}$ & 1654 & 2073 & 121 & 430 & 1161 & 1402 & 900 & 4779 & 4014 \\
\hline Jan & 48 & $\underline{213}$ & $\underline{820}$ & 1617 & 2052 & 100 & 416 & 1168 & 1451 & 900 & 4750 & 4035 \\
\hline Feb & 50 & 205 & $\underline{772}$ & 1576 & 1925 & 134 & 429 & 1124 & 1320 & 847 & 4528 & 3854 \\
\hline Mar & 40 & 191 & 734 & 1584 & 1811 & 128 & 407 & 1095 & 1308 & 875 & 4360 & $\frac{2.78}{3813}$ \\
\hline Apr & 39 & $\underline{228}$ & 753 & 1448 & 1768 & 119 & 422 & 1158 & 1285 & $\frac{01}{792}$ & 4236 & 3776 \\
\hline May & 52 & $\frac{220}{180}$ & 657 & 1316 & 1700 & 116 & 395 & 1092 & 1260 & 795 & 3905 & 3658 \\
\hline Jun & 33 & 182 & 680 & 1281 & 1558 & $\underline{129}$ & $\underline{442}$ & 1035 & 1274 & 793 & 3734 & 3673 \\
\hline Jul & 39 & 182 & 617 & 1268 & 1478 & $\frac{127}{107}$ & 353 & 976 & 1226 & 779 & 3584 & 3441 \\
\hline Significance & NS & $*$ & $* * *$ & $* * *$ & $* * *$ & NS & NS & $* * *$ & $* *$ & $* *$ & $* * *$ & $* * *$ \\
\hline
\end{tabular}

Cosinor analysis using 12 monthly variables.

NS $=$ not significant ${ }^{*} \mathrm{p}<0 \cdot 05,{ }^{* *} \mathrm{p}<0 \cdot 01,{ }^{* * *} \mathrm{p}<0 \cdot 001$.

The three highest monthly totals for each combination of gender, age group, and outcome are underlined.

The data have been month corrected.

Table 2 Cosinor analysis

\begin{tabular}{|c|c|c|c|c|c|c|c|c|c|c|}
\hline & \multicolumn{5}{|l|}{ Men } & \multicolumn{5}{|c|}{ Women } \\
\hline & $r$ & $p$ & Amplitude & Mean & Peak & $r$ & $p$ & Amplitude & Mean & Peak \\
\hline $\begin{array}{l}\text { Deaths } \\
\text { All }\end{array}$ & 0.93 & $<0.001$ & $11 \cdot 1$ & 6589 & Jan & 0.97 & $<0.001$ & $13 \cdot 7$ & 4131 & Jan \\
\hline $\begin{array}{l}\text { Age group: } \\
<45 \\
45-54 \\
55-64 \\
65-74 \\
>75\end{array}$ & $\begin{array}{l}0 \cdot 7 \\
0 \cdot 86 \\
0 \cdot 88 \\
0 \cdot 92 \\
0.92\end{array}$ & $\begin{array}{l}<0.05 \\
<0.01 \\
<0.01 \\
<0.001 \\
<0.001\end{array}$ & $\begin{array}{r}10 \cdot 0 \\
9 \cdot 2 \\
9 \cdot 8 \\
11 \cdot 4 \\
14 \cdot 4\end{array}$ & $\begin{array}{r}235 \\
801 \\
1896 \\
2135 \\
1520\end{array}$ & $\begin{array}{l}\text { Mar } \\
\text { Feb } \\
\text { Jan } \\
\text { Jan } \\
\text { Jan }\end{array}$ & $\begin{array}{l}0.68 \\
0.74 \\
0.93 \\
0.95 \\
0.95\end{array}$ & $\begin{array}{l}\text { NS } \\
<0.05 \\
<0.001 \\
<0.001 \\
<0.001\end{array}$ & $\begin{array}{l}17 \cdot 7 \\
10 \cdot 4 \\
11 \cdot 9 \\
13 \cdot 8 \\
14 \cdot 8\end{array}$ & $\begin{array}{r}45 \\
193 \\
710 \\
1434 \\
1748\end{array}$ & $\begin{array}{l}\text { Dec } \\
\text { Jan } \\
\text { Jan } \\
\text { Jan } \\
\text { Jan }\end{array}$ \\
\hline $\begin{array}{l}<55 \\
>55\end{array}$ & $\begin{array}{l}0.86 \\
0.93\end{array}$ & $\begin{array}{l}<0.01 \\
<0.001\end{array}$ & $\begin{array}{r}9 \cdot 1 \\
11 \cdot 6\end{array}$ & $\begin{array}{l}1037 \\
5551\end{array}$ & $\begin{array}{l}\text { Feb } \\
\text { Jan }\end{array}$ & $\begin{array}{l}0.77 \\
0.97\end{array}$ & $\begin{array}{l}<0.05 \\
<0.001\end{array}$ & $\begin{array}{l}11 \cdot 2 \\
13 \cdot 9\end{array}$ & $\begin{array}{r}238 \\
3893\end{array}$ & $\underset{\text { Jan }}{\text { Jan }}$ \\
\hline $\begin{array}{l}\text { Admissions } \\
\text { All }\end{array}$ & $0 \cdot 56$ & NS & $2 \cdot 7$ & 6766 & May, Dec & 0.9 & $<0.001$ & $7 \cdot 1$ & 3716 & Jan \\
\hline $\begin{array}{c}\text { Age group: } \\
<45 \\
45-54 \\
55-64 \\
65-74 \\
>75\end{array}$ & $\begin{array}{l}0.75 \\
0.49 \\
0.66 \\
0.23 \\
0.63\end{array}$ & $\begin{array}{l}<0 \cdot 05^{*} \\
\text { NS } \\
\text { NS } \\
\text { NS } \\
\text { NS }\end{array}$ & $\begin{array}{l}5 \cdot 7 \\
2 \cdot 3 \\
3 \cdot 7 \\
1 \cdot 1 \\
6 \cdot 2\end{array}$ & $\begin{array}{r}596 \\
1480 \\
2483 \\
1564 \\
641\end{array}$ & $\begin{array}{l}\text { May, Nov } \\
\text { May, Dec } \\
\text { May, Nov } \\
\text { May, Dec } \\
\text { May, Dec }\end{array}$ & $\begin{array}{l}0.54 \\
0.56 \\
0.91 \\
0.82 \\
0.86\end{array}$ & $\begin{array}{l}\text { NS } \\
\text { NS } \\
<0.001 \\
<0.01 \\
<0.01\end{array}$ & $\begin{array}{l}7 \\
5 \cdot 7 \\
8 \cdot 6 \\
7 \cdot 1 \\
7\end{array}$ & $\begin{array}{r}115 \\
415 \\
1078 \\
1284 \\
822\end{array}$ & $\begin{array}{l}\text { Mar } \\
\text { Dec } \\
\text { Jan } \\
\text { Jan } \\
\text { Jan }\end{array}$ \\
\hline $\begin{array}{l}<55 \\
>55\end{array}$ & $\begin{array}{l}0.61 \\
0.58\end{array}$ & $\begin{array}{l}\text { NS } \\
\text { NS }\end{array}$ & $\begin{array}{l}3 \cdot 1 \\
3 \cdot 0\end{array}$ & $\begin{array}{l}2077 \\
4689\end{array}$ & $\begin{array}{l}\text { May, Dec } \\
\text { May, Dec }\end{array}$ & $\begin{array}{l}0.5 \\
0.91\end{array}$ & $\begin{array}{l}\text { NS } \\
<0.001\end{array}$ & $\begin{array}{l}4 \cdot 8 \\
7 \cdot 5\end{array}$ & $\begin{array}{r}531 \\
3185\end{array}$ & $\begin{array}{l}\text { June, Nov } \\
\text { Jan }\end{array}$ \\
\hline
\end{tabular}

* Two peaks but the earlier is much the larger and its cosinor analysis is significant.

Table 3 Coronary incidence in relation to month, sex, and age group

\begin{tabular}{|c|c|c|c|c|c|c|c|c|c|c|c|c|c|c|c|c|}
\hline & \multicolumn{5}{|l|}{ Men } & \multicolumn{5}{|l|}{ Women } & \multicolumn{2}{|l|}{ Total } & \multicolumn{2}{|l|}{ Age $<55 y$} & \multicolumn{2}{|c|}{ Age $>55 y$} \\
\hline & $<45 y$ & $45-54 y$ & $55-64 y$ & $65-74 y$ & $75+y$ & $<45 y$ & $45-54 y$ & $55-64 y$ & $65-75 y$ & $74 y$ & Men & Women & Men & Women & Men & Women \\
\hline $\begin{array}{l}\text { Month: } \\
\text { August } \\
\text { September } \\
\text { October } \\
\text { November } \\
\text { December } \\
\text { January } \\
\text { February } \\
\text { March } \\
\text { April } \\
\text { May } \\
\text { June } \\
\text { July }\end{array}$ & $\begin{array}{l}734 \\
765 \\
751 \\
756 \\
791 \\
760 \\
752 \\
836 \\
837 \\
860 \\
836 \\
785\end{array}$ & $\begin{array}{l}2017 \\
1977 \\
2062 \\
2052 \\
\frac{2259}{2194} \\
\frac{21990}{2176} \\
2113 \\
\frac{2195}{2101} \\
2068\end{array}$ & $\begin{array}{l}3640 \\
3598 \\
3731 \\
4050 \\
\frac{4215}{4053} \\
4095 \\
4081 \\
3961 \\
3942 \\
3938 \\
3803\end{array}$ & $\begin{array}{l}3051 \\
3113 \\
3052 \\
\frac{3341}{3566} \\
3540 \\
3329 \\
3263 \\
3212 \\
3178 \\
3112 \\
2917\end{array}$ & $\begin{array}{l}1672 \\
1697 \\
1758 \\
1879 \\
\underline{2099} \\
\underline{2142} \\
2049 \\
\frac{2063}{1802} \\
1811 \\
1707 \\
1606\end{array}$ & $\begin{array}{l}127 \\
138 \\
162 \\
158 \\
\frac{166}{142} \\
\frac{167}{164} \\
\frac{151}{153} \\
159 \\
138\end{array}$ & $\begin{array}{l}487 \\
541 \\
595 \\
604 \\
587 \\
575 \\
578 \\
550 \\
598 \\
538 \\
576 \\
496\end{array}$ & $\begin{array}{l}1400 \\
1494 \\
1534 \\
1653 \\
\frac{1729}{1741} \\
\frac{1668}{1610} \\
1658 \\
1567 \\
1513 \\
1416\end{array}$ & $\begin{array}{l}2044 \\
2166 \\
2185 \\
2429 \\
\frac{2630}{2600} \\
\frac{2681}{2481} \\
2350 \\
2218 \\
2181 \\
2121\end{array}$ & $\begin{array}{l}1956 \\
2002 \\
2144 \\
2295 \\
\frac{2533}{2520} \\
\frac{2562}{2362} \\
2251 \\
2201 \\
2104 \\
2018 \\
1942\end{array}$ & $\begin{array}{l}11114 \\
11150 \\
11354 \\
12078 \\
12930 \\
\frac{12689}{12315} \\
\frac{12419}{11925} \\
11986 \\
11676 \\
11179\end{array}$ & $\begin{array}{l}6014 \\
6341 \\
6620 \\
7139 \\
7643 \\
7578 \\
7256 \\
7035 \\
6960 \\
6580 \\
6447 \\
6113\end{array}$ & $\begin{array}{l}2751 \\
2742 \\
2813 \\
2808 \\
\frac{3050}{2954} \\
2842 \\
3012 \\
\frac{2950}{3055} \\
2938 \\
2853\end{array}$ & $\begin{array}{l}614 \\
679 \\
757 \\
762 \\
753 \\
717 \\
745 \\
714 \\
\frac{749}{691} \\
735 \\
634\end{array}$ & $\begin{array}{l}8363 \\
8408 \\
8541 \\
9270 \\
\frac{9880}{9735} \\
9473 \\
9407 \\
8975 \\
8931 \\
8738 \\
8326\end{array}$ & $\begin{array}{l}5400 \\
5662 \\
5863 \\
6377 \\
\frac{6892}{6861} \\
\frac{6511}{6321} \\
6211 \\
5889 \\
5712 \\
5479\end{array}$ \\
\hline $\begin{array}{l}\text { Cosinor analysis: } \\
\mathbf{r} \\
\mathrm{p} \\
\text { Amplitude (\%) } \\
\text { Mean } \\
\text { Acrophase } \\
\end{array}$ & $\begin{array}{l}0.79 \\
<0.05 \\
6 \\
788 \\
\text { Apr/May }\end{array}$ & $\begin{array}{l}0 \cdot 68 \\
\text { NS } \\
3 \cdot 5 \\
2108 \\
\text { Feb/Mar }\end{array}$ & $\begin{array}{l}0 \cdot 83 \\
<0 \cdot 01 \\
5 \cdot 3 \\
3925 \\
\text { Jan/Feb }\end{array}$ & $\begin{array}{l}0 \cdot 87 \\
<0 \cdot 01 \\
7 \cdot 1 \\
3222 \\
\text { Jan }\end{array}$ & $\begin{array}{l}0.92 \\
<0.001 \\
12 \cdot 2 \\
1857 \\
\text { Jan }\end{array}$ & $\begin{array}{l}0 \cdot 59 \\
\text { NS } \\
6 \cdot 6 \\
152 \\
\mathrm{Jab} / \mathrm{Feb}\end{array}$ & $\begin{array}{l}0 \cdot 7 \\
\text { NS } \\
6 \cdot 5 \\
560 \\
\text { Jan }\end{array}$ & $\begin{array}{l}0.95 \\
<0.001 \\
9 \\
1581 \\
\text { Jan }\end{array}$ & $\begin{array}{l}0.94 \\
<0.001 \\
10.6 \\
2322 \\
\text { Jan }\end{array}$ & $\begin{array}{l}0.95 \\
<0 \cdot 001 \\
11.9 \\
2194 \\
\text { Jan }\end{array}$ & $\begin{array}{l}0 \cdot 89 \\
<0 \cdot 001 \\
6 \cdot 1 \\
11901 \\
\text { Jan }\end{array}$ & $\begin{array}{l}0.96 \\
<0 \cdot 001 \\
10 \cdot 2 \\
6810 \\
\text { Jan }\end{array}$ & $\begin{array}{l}0 \cdot 71 \\
<0.05 \\
3 \cdot 6 \\
2897 \\
\text { Mar/Apr }\end{array}$ & $\begin{array}{l}0 \cdot 69 \\
\text { NS } \\
6 \cdot 4 \\
712 \\
\text { Jan }\end{array}$ & $\begin{array}{l}0.91 \\
<0 \cdot 001 \\
7.3 \\
9003 \\
\text { Jan }\end{array}$ & $\begin{array}{l}0.95 \\
<0.001 \\
10.6 \\
6098 \\
\text { Jan }\end{array}$ \\
\hline
\end{tabular}

The three highest month totals for each combination of gender and age group are underlined. 


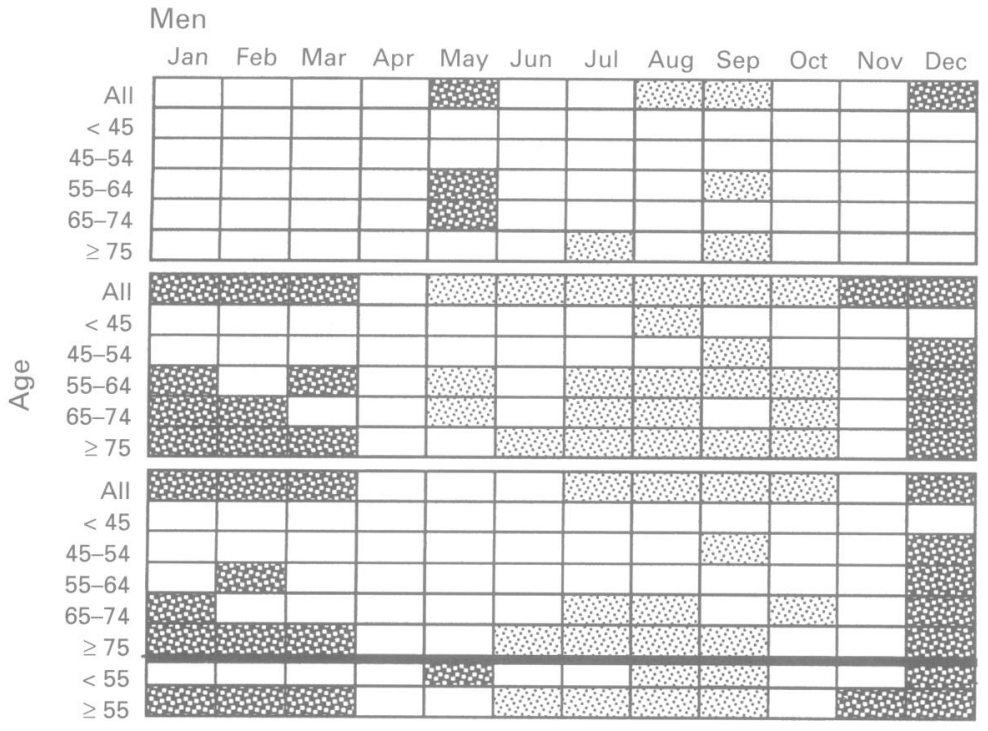

Women

Jan Feb Mar Apr May Jun Jul Aug Sep Oct Nov Dec

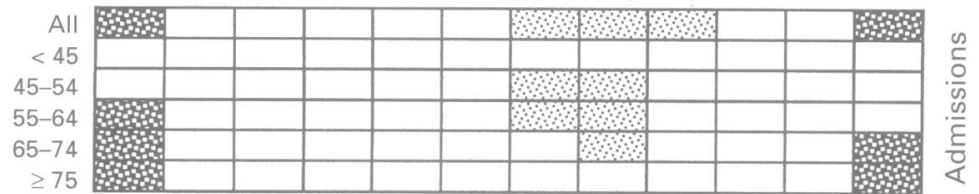

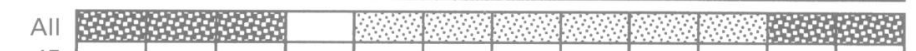

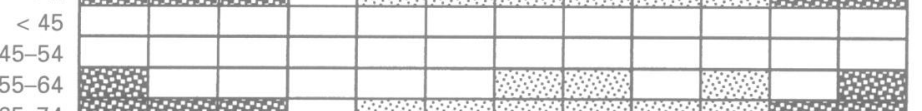

$55-64$

$65-74$

$\geq 75$

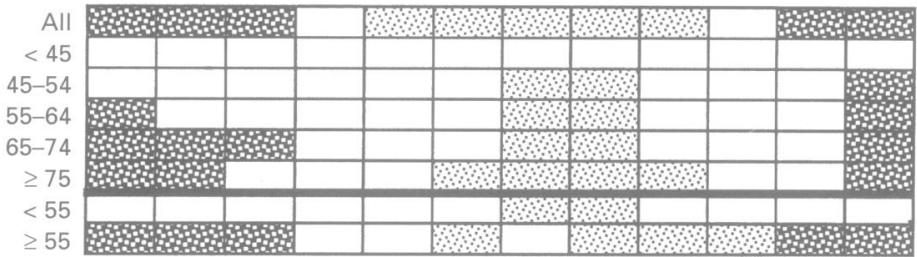

Significantly above expected value

Figure 4 Incidence, deaths, and hospital admissions for comnary heart disease in relation to age and sex in Scotland (1962-71). The dark areas are months which are significantly higher than the mean and the lightly stippled areas are significantly lower than the mean. Where there is no entry these points were not significantly different from the mean. The level of significance is $p<0.01$.

COMPARISON WITH CONCEPTIONS (FIG 6)

The General Register Office for Scotland also provided data for births between 1962 and 1971. Dates of conceptions are assumed from the dates of birth. Seasonal variation in conception has its main peak one month after the spring peak for $\mathrm{CHD}$ in men under 45 years (see fig 6). There is a further secondary one month peak for conceptions in January, but the small November secondary peak in CHD male admissions is non-significant.

\section{Discussion}

The original study ${ }^{1}$ covered 1962-66; we have added to it corresponding data for 1967-71. This has made possible clarification of the earlier results, with emphasis on hospital admissions. In recent times there has been an interest in the circadian rhythm of $\mathrm{CHD}$ events $^{78}$ but no reports of seasonality of CHD focussing on non-fatal onsets. We recognise the limitations of death certification, hospital discharge documentation, and record linkage. In the earlier survey, the records of 1000 admissions under rubric ICD 420.1 showed that $87 \%$ were due to acute myocardial infarction or acute ischaemia. The term admissions has been used loosely; these are recorded as hospital discharges - that is, those who were admitted and then died or were discharged.

The familiar association between low environmental temperature and CHD mortality has been discussed in detail previously. ${ }^{910}$ Our evidence suggests that this may result from the fall in temperature in autumn and early winter, rather than the absolute low temperature reached in later winter. ${ }^{6}$ Other meteorological and environmental influences may also be involved. The effector mechanism, however, is unclear. In addition to changes in cholesterol ${ }^{10}$ and blood pressure ${ }^{112}$ there are winter increases in haematocrit, ${ }^{1314}$ white cell count, ${ }^{15}$ and fibrinogen concentration, ${ }^{1617}$ all of which raise blood viscosity; while fibrinolysis is most active in the summer. ${ }^{18}$ Factor VII clotting activity, C-reactive protein, and $\alpha$ antitrypsin values are also raised in winter. ${ }^{16}$

The age related spring increase in CHD nonfatal onsets is a predominantly male phenomenon. The dominant pattern of spring/ autumn variation in the youngest male age group is replaced in older male age groups by a bimodal pattern in which a gradually declining spring peak exceeds the winter peak until old age ( $>75$ years). In contrast, women aged 55 and over show a dominant pattern of winter/ summer variation in CHD non-fatal onsets. The numbers in the younger female age groups are small, and a firm conclusion must await an even larger series. Seasonal variation in deaths shows a dominant winter/summer pattern in both sexes, with subsidiary spring "shoulders" on the winter peak in the two youngest male age groups. The results of examination of coronary incidence in men under 55 years of age strengthen these conclusions. The cause of the age related spring peak in non-fatal onsets is uncertain, but a risk factor which is dominant in younger men, reduces with age, and is inconspicuous in women suggests an androgenically driven effector mechanism. There is a similarity between seasonal variation of conceptions and non-fatal coronary onsets in young men. Moreover, seasonal variation in beard growth, ${ }^{19}$ rape and attempted rape (AS Douglas, personal communication, ${ }^{20-21}$ ) spermatogenesis, ${ }^{22-24}$ and levels of oestradiol ${ }^{25}$ and luteinizing hormone ${ }^{26}$ all show spring-summer peaks.

The effector mechanism through which a putative spring increase in androgenic activity might operate is also speculative. Two studies of seasonal variation in serum cholesterol in Scotland $\mathrm{d}^{27}$ and Israel ${ }^{28}$ found the highest values in the spring, but a larger study of two-monthly seasonal variation in the United States showed a high winter, low summer pattern, ${ }^{10}$ as have most other studies. ${ }^{29}$ Seasonal variation in blood pressure in most reports shows a dom- 

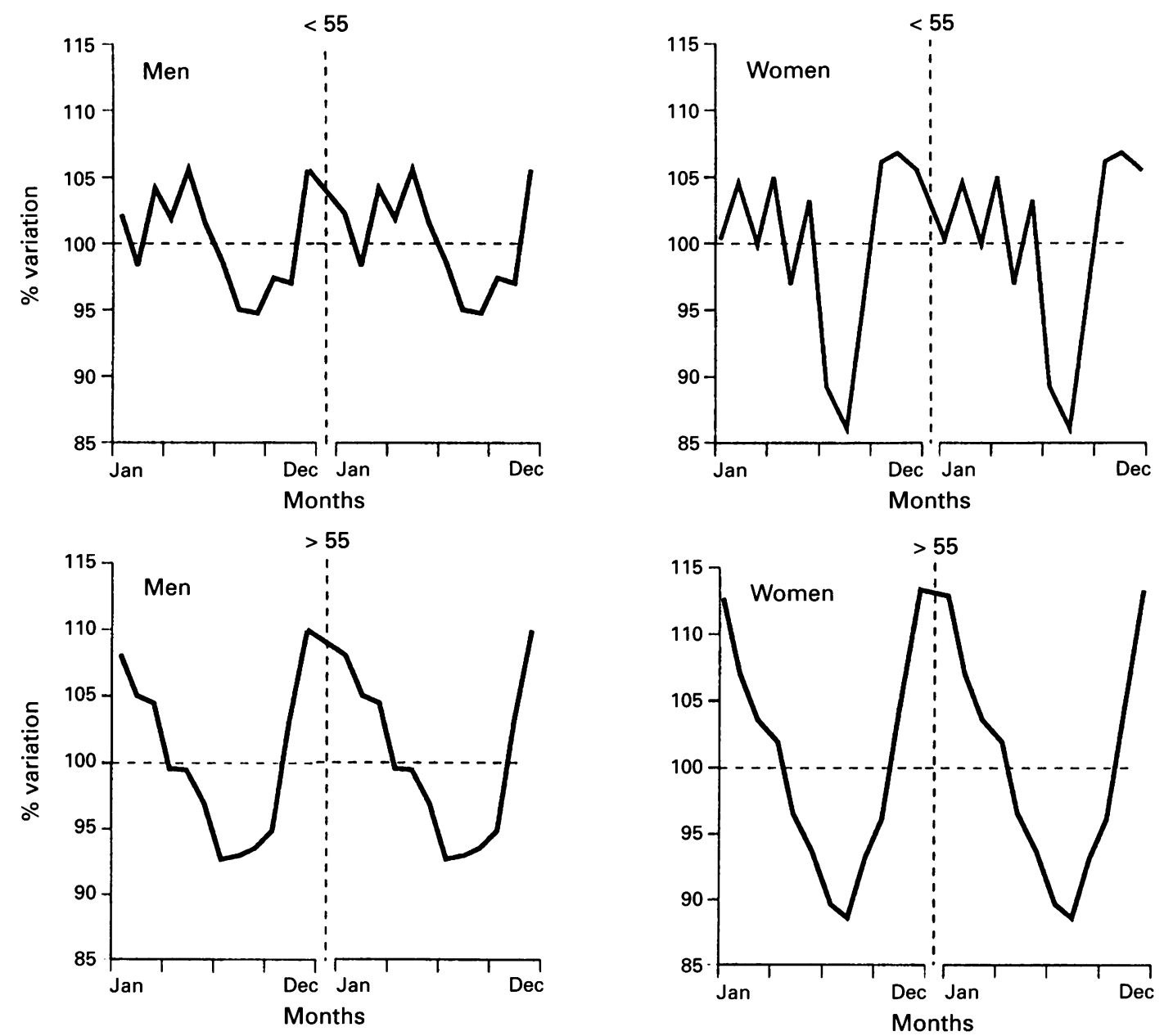

Figure 5 Incidence of coronary heart disease in Scotland (1962-71) for men and women under 55 years and 55 years or above. Incidence means coronary death and non-fatal myocardial infarction. The vertical axis is scaled to percentages above and below the mean monthly value (100\%). The horizontal axis gives the value by month. The second half of each diagram repeats the first half to illustrate the pattern of seasonal variation.

inant high winter, low summer pattern ${ }^{11} 12$ with a few showing a spring peak, for example, ${ }^{30}$; Eastham and Avis $^{31}$ found adhesive platelet counts to be highest and non-adhesive counts lowest in the spring. Lacoste and Wirz-Justice ${ }^{11}$ found a spring/autumn pattern of platelet serotonin uptake strikingly similar to the spring/ autumn pattern of CHD variation in the youngest group of Scottish men in the present study. Unfortunately, however, none of the foregoing studies were grouped according to age and sex. The seasonality of several parameters has been

CHD discharges $<45$ y

Conceptions
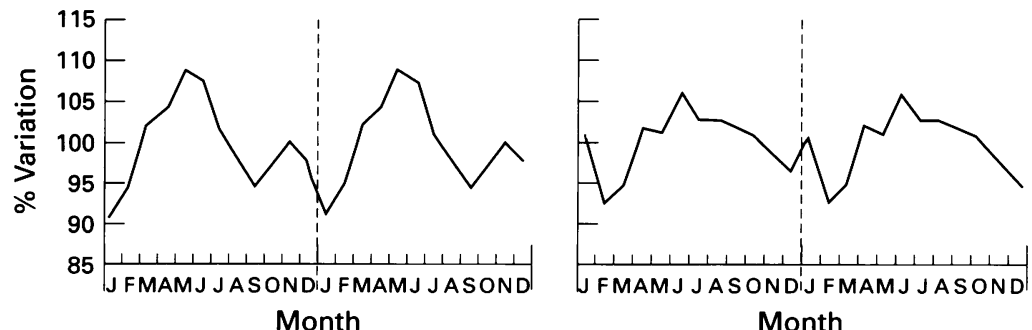

Figure 6 Discharge from hospital after an episode of coronary heart disease in men $<45$ years and conceptions in Scotland 1962-71. The vertical axis is scaled to percentages above and below the mean monthly value (100\%). The horizontal axis gives the value by month. The second half of each diagram repeats the first half to illustrate the pattern of seasonal variation more clearly. discussed, quoting only a small number of the available published papers. This paper is not a review: a recent bibliography ${ }^{29}$ provides a fuller reference source.

It is possible that the male, age related spring rise in CHD prevalence results from the emotional and physical effects of increased sexual activity in spring in men with pre-existing cardiovascular disease. It may also be relevant that the incidence of suicide peaks in May, and that its amplitude is greater in men than in women (A S Douglas personal communication).

Confirmatory studies of the pattern of seasonal variation in CHD non-fatal onsets shown in the present study are desirable, utilising comparably large data sets. Further elucidation of the mechanism of the spring rise in CHD incidence in men would require larger studies of seasonal variation in major cardiovascular risk factors and reproductive hormones divided by age and sex.

ASD held a Leverhulme Research Fellowship, and other funds supporting the study came from Maryland Medical Research Institute and Boehringer-Ingelheim Ltd. We thank the Research and Intelligence Unit of the Scottish Home and Health Department for inpatient data, and the General Register Office, partment for inpatient data, and the General Register Office, thank Dr Daphne Russell for statistical guidance, the staff of thank Dr Daphne Russell for statistical guidance, the staff of
Aberdeen University Medical School Library, Mrs M Burnett for multiple typings of the manuscript. The art work was done for multiple typings of the manuscript. The art work was done Glasgow and the Medical School, Aberdeen. 
1 Dunnigan MG, Harland WA, Fyfe T. Seasonal incidence and mortality of ischaemic heart disease. Lancet 1970; 793-797.

2 Westlund $\mathrm{K}$. Further observations on the incidence of myocardial infarction. Fournal of Oslo City Hospital 1965;15: 203-31.

3 Anderson TW, Le Riche WH. Seasonal variation in ischaemic heart disease. Lancet 1970;ii: 1140.

4 Halberg F, Johnson EA, Nelson W, Runge W, Southern R. Autorhythmometry - procedures for physiological selfAutorhythmometry - procedures for physiological self-
measurements and their analysis. Physiology Teacher 1972; 1(4):1-11.

5 Douglas AS, Allan TM, Rawles JM. Composition of seasonality of disease. Scot Med f 1991;36:76-82.

6 Douglas AS, Al-Sayer H, Rawles JM, Allan TM. Seasonality of disease in Kuwait. Lancet 1991;337:1393-97.

7 Muller JE, Stone PH, Turi ZG, Rutherford JD, Czeisle $\mathrm{CA}$, Parker C. Circadian variation in the frequency of onset of acute myocardial infarction. N Engl ₹ Med 1985; 313:1315-22.

8 Muller JE, Ludmer PL, Willich SN, Tofler GH, Aylmer G, Klagnos I. Circadian variation in the frequency of sudden cardiac death. Circulation 1987;75:131-8.

9 Rose G. Cold weather and ischaemic heart disease. $\mathrm{Br} \mathcal{F}$ Prev Soc Med 1966;20:97-100.

10 Gordon DJ, Trost DC, Hyde J, Whaley FS, Hannan PJ, Jacobs DR, Ekelend L-G. Seasonal cholesterol cycles: the Lipid Research Clinics Coronary Primary Prevention Trial Placebo Group. Circulation 1987;76:1224-31.

11 Lacoste V, Wirz-Justice A. Seasonal variation in normal subjects: an update of variables current in depression research. In: Rosenthal NE, Blehar MC, eds. Seasonal affective disorders and phototherapy. New York, London Guildford Press, 1989;167-229.

12 Brennan PJ, Greenberg C, Miall WE, Thompson SF. Seasonal variation in arterial blood pressure. $B M \mathcal{F} 1982 ; 285$ 919-23.

13 Riggs HE, Boles RS, Reinhold JG, Shore PS. Observations on the chemical composition of the blood and on some cardiovascular reactions in chronic peptic ulcer throughout one year. Gastroenterology 1944;3:480-9.

14 Touitou Y, Touitou C, Bogdan A, et al. Differences between young and elderly subjects in seasonal and circadian variyoung and elderly subjects in seasonal and circadian vari-
ations of total plasma proteins and blood volume as reflected by haemoglobin, haematocrit and erythrocyte flected by haemoglobin, haematocri

15 Hampf $\mathrm{C}$. Forekomma Sasong variationer i blodbilden hos befoekningen i Finland (Seasonal variations in blood pic- ture in the population of Finland). Finska Läkaresällskapets Handelingar 1936;79:141-61.

16 Woodhouse PR, Khaw KT, Plummer M, Foley A, Meade TW. Seasonal variations of plasma fibrinogen and factor V11 activity in the elderly: winter infections and death from cardiovascular disease. Lancet 1994;343:435-9.

17 Stout RW, Crawford V. Seasonal variations in fibrinogen concentrations among elderly people. Lancet 1991;338: 9-13.

18 McLaren M, Lou C, Forbes CD, Belch JP. Seasonal variation in fibrinolysis in patients with rheumatoid arthritis. ation in fibrinolysis in patients with
Fibrinolysis 1990;4(suppl 2):116-17.

19 Randall VA, Ebling FB. Seasonal changes in human hair growth. Br f Dermatol 1991;134:146-51.

20 Lombroso C. Crime. Its courses and remedies. London: Heinemann, 1911

21 Aschaffenburg G. Crime and its repression. London: Heinemann, 1913.

22 Mortimer D, Templeton AA, Linton EA, Coleman RA. Annual patterns of human sperm production and semen quality. Arch Androl 1983;10:1-3.

23 Levine RJ, Mathew RM, Chenoult B, Brown MH, Hurtt $M E$, Bentley KS. Difference in the quality of semen in outdoor workers during summer and winter. $N$ Engl $f$ Med 1990;323:12-16.

24 Politoff L, Birkhauser M, Almendral A, Zorn A. New data confirming a circannual rhythm in spermatogenesis. Fertil Confirming a circannua

25 Baker HWG, Burger HG, de Kretser DM, Hudson B, O'Connor S, Wange C. Changes in the pituitary-testicular system with age. Clin Endocrinol 1976;5:349-72.

26 Touitou Y, Lagoguey M, Bogdan A, Reinberg A, Beck H. Seasonal rhythms of plasma gonadotrophins: their persistence in elderly men and women. $\mathcal{F}$ Endocrinol 1983; 96:15-21.

27 Fyfe T, Dunnigan MG, Hamilton E, Rae RJ. Seasonal variation in serum lipids and incidence and mortality of ischaemic heart disease. 7 Atheroscler Res 1968;8:591-6.

28 Harlap S, Kark JD, Baras M, Eisenberg S, Stein Y. Seasonal changes in plasma lipids and lipoprotein levels in Jerusalem. Isr F Med Sci 1982;18:1158-65.

29 Allan TM, Douglas AS. Seasonal variation in health and diseases: a bibliography. London, New York: Mansell, 1994.

30 diseases: a bibliography. London, New York: Mansell, 1994. 1961;189:235.

31 Eastham RD, Avis PRD. Seasonal variation in adhesive platelets during long term anticoagulant therapy. $B r f$ Haematol 1966;12:39-43. 